\title{
The Soviet Cinema of 1920s: Problems, Tendency and Tasks
}

\begin{abstract}
The article shows how the Bolsheviks organized the cinematographic process in 1920s and what problems they faced. It interprets the meaning of the "national cinema" with a view to understand how it impacted feature films. It examined, as an example, the Jewish cinema experience. The canon of plot schemes and schemes of heroes is analyzed based on the cinema press and feature films.
\end{abstract}

Keywords: the Bolsheviks, propaganda tool, the Soviet cinema, a cinema press, a "national" film, the Jewish cinema, shtetl, traditional images, new images

When the Bolsheviks seized power in 1917, first of all, they tried to build a new state with a new entity, create new ideals and values. However, the Bolsheviks faced social and economic problems, which emerged after the First World War and the February Revolution. Even in these circumstances, Lenin had paid attention to the development of film industry as a propaganda tool. Considering the lack of raw resources, human resources, and funding in the film industry, they started with launching newsreels and short films because it was cheaper than feature films. The most appropriate places, more precisely, the target audience for presenting new created films were factories, schools, universities, and villages. For the first time in the Party Programme, adopted at the $8^{\text {th }}$ Party Congress of RCP (b) in 1919, film was officially recognized as a main tool for extracurricular education $^{1}$. Subsequently, the Soviet authority was making films with the aim to form and support a concept of the new Soviet man.

The cinema industry has come under the Bolshevik control on August 1919, when Lenin signed the decree of The Transfer of Photographic and Cinematographic

${ }^{1}$ N.A. Lebedev, Ocherk istorii kino SSSR: Nemoe kino (1918-1934), Moscow 1965, p. 15. 
Trade and Industry to the Jurisdiction of the People's Commissariat for Education. Nevertheless, the real nationalization of cinema industry was finished in the end of 1920s. It means that there was a significant difference between what Bolshevik documents, including programs, plans, and decrees claimed and the actual reform implementation in the cinema industry. Moreover, the cinematographic press in the early 1920s frequently wrote that with the advent of Bolsheviks "cinema is beginning the chaotic revival" 2 . In the end of 1920s in the literature of the Party and cinematography a trend towards criticism of the previous authority emerged. For instance, "The proletariat inherited nothing. Neither the cinema factory nor the necessary equipment nor enough qualified workers", stated cinema critic Bush in $1929^{3}$. In this case, critical rhetoric was used as a justification for the situation in the Soviet cinema industry. On the First All-Union Party Conference on Cinema of March 1928 it was remarked that from 1925 to $192679 \%$ of films were imported from abroad ${ }^{4}$. It was a major problem during 1920 s and the Bolsheviks created a permissions system for foreign products in response to smuggling films. On 19 December 1922, the State Film Organization (Goskino) was given monopoly over the distribution of all films; additionally, Goskino was renamed Sovkino in 1924. Anyway, the Bolsheviks did not solve the question of the films smuggling. As an example, the article of the cinema newspaper "Kino" remarked that films regularly got into the Soviet territory without information where they were released and who were the authors, actors, and in which country they were produced ${ }^{5,6}$.

The Party emphasized that the complicated situation of cinema industry is due to the absence of proper employees in the industry. Although given the Soviet cinema press, the film studios had problems with qualified staff during the existence of the Soviet Union. Indeed, in 1920s this question was particularly acute. By the way, the possibility to get a job without appropriate education or with no special education was acceptable. Many well-known cinema masters moved to film production from different branches, which were not associated with cinema. Obviously, there emerged a necessity for a new cinema staff. During the 1920s many schools were established for directors, editors, writers, and actors. Each edition of the cinema magazine or newspaper advertised cinema-schools and discussed who is an ideal film master. "To find appropriate workers for the cinema production"

2 Kino. Dvuhnedelnyk kynodeyateley 1922, no. 1, p. 1.

${ }^{3}$ M. Bush, Nayvazlyvishe z Mystetstv, Kyiv 1929, pp. 30-31.

${ }^{4}$ M.I. Zhabskyy, Vesternyzatsyya kynematohrafa: opyt i uroky, Sotsiologicheskie Yssled 1996, no. 2, p. 27.

${ }^{5}$ L.A. Lyberman, ZavHoskyno. Kino. Dvuhnedelnyk kynodeyateley 1922, no. 3-6, p. 19.

${ }^{6}$ Kino Zhurnal A.R.C 1924, no. 1, p. 36. 
was said in the Resolution of the RCP (b) ${ }^{7}$. According to the Resolution of the Secretariat of the Central Committee of the Communist Party of the Soviet Union of 11 January 1929, cinema factories had to cooperate with groups of writers ${ }^{8}$, etc.

The chaotic development of the Soviet cinema industry of 1920s appeared to be uncontrolled by the new authorities. In the first decade of the governing, the party step by step organized the cinema industry into one crucial system. Ultimately, the Party demanded from film factories the "proper" cinema products according to ideology values. In the end of 1920s the Soviet cinema industry had turned into a central system which was led by the Communist Party. First, the Bolsheviks organized the filming production all over the country, and second, they issued precise guidelines how to create films and what the main points in the film must be.

\section{“National” Film}

Many national communities and minorities were living on the territory of the Soviet Union; moreover, the Soviet Union consisted of Republics. In other words, the majority of Republics had their own film factories and theoretically they could launch their own films without the censorship of the central authorities. It should be noted that censorship, first of all, was used in the printed materials, books, theaters, and music. Interestingly, censorship avoided films, although the $12^{\text {th }}$ Congress of the RCP (B) in April 1923 approved that "a cinema like all art cannot be apolitical". In 1922 the newspaper "Kino" mentioned how to use censorship in feature films in Kyiv. Censorship consisted of military censor GPU ${ }^{10}$ and representatives from the central cinema organization of the Republic. Censorship had banned those films that had a detective, religious or non-full character ${ }^{11}$.

Among the propaganda tools, feature films were also used by the Soviet authorities. In May 1924 the newspaper "Kino Tyzden" printed the article Tasks for the Cinema in the Ethnography. In that article the importance of cinema in relation with the national policy was discussed in order to show the "peculiarities of nations and their living conditions", besides, it stressed the new order of the new

7 Vlast' i chudožestvennaja intelligencija: dokumenty CK RKP(b) - VKP(b), VČK - OGPU NKVD o kul'turnoj politike: 1917-1953 gg, ed. A.N. Yakovleva, Moskva 1999, p. 44.

${ }^{8}$ Ibidem, p. 43-44.

9 D. Baturov, Partia i Lenin, Lyiv 1930, p. 30-31.

${ }^{10}$ State Political Directorate in the Soviet Union

${ }^{11}$ Kino. Dvuhnedelnyk kinodeatelej 1922, no. 2, p. 33. 
society ${ }^{12}$. In that period no exact instructions for national films existed because there were so few of them. Scheme-templates of film plots and images of heroes for national films appeared only after 1925. Films about the lives of different nationalities made between 1925 and 1926 can be classified into four themes:

1. national pre-revolution films about the struggle of the people against the tsar's power, especially focusing on the middle of the nineteenth century;

2. the Revolution of 1905;

3. the Russian Civil War 1917-1922;

4. films about the traditional way of life in the tsarist Russia.

For example, analyzing films of 1926, we can notice this tendency. The film Abrek Zaur shows how the mountain people of the Caucasus in the mid-nineteenth century fought with the tsar's power, and the film Alim refers to the struggle of the Tatar people with tsar's bureaucracy in the same period. The film Baht Kuyashy shows how the Uzbek people fought due to the poor implementation of the decree on the land, and, additionally, the events unfolding in the middle of the nineteenth century. Then, the film Zare is about the life of the Kurds in the Caucasus and their struggle against the tsar's policy.

Another theme was the Revolution of 1905. For instance, the picture Machinist Ukhtomsky presents how an employee of the Moscow-Kazan railway supported the Moscow uprising of workers in the days of the Revolution of 1905. The plot of the film Protiv Voli Ottsov (Against the Will of the Fathers) shows the participation of Jews in the revolutionary events in 1905.

There are cinema stories based on the events of the Civil War like Ukrainian films The Trypillia Tragedy and Blue Package. The film Mamut and Aisha presents the underground work against the Whites in the Crimea.

The film Under the Rule of Adat tells about the religious traditions of the "old" Caucasus and the fanatical faith, and the Armenian film Namus depicts prerevolutionary petty bourgeoisie, which faced conflicts over religion.

These cinema themes had remained until the end of the 1920s, and the only thing that changed was the tendency to reduce the number of films about the imperial past of the nineteenth century. Eventually, in 1925 a tide of criticism directed at the detailed presentation of traditions and religious backgrounds in the films was rising. Instead, stressed were the three dates that should inspire writing scripts and shooting them; this topic was covered in an article called 1905-1917-1925 published in the magazine "Kino Zhurnal ARK"13. Mainly, it was neces-

${ }_{12}$ Zadachi kino v oblasti etnographii, Kino Nedelya 1924, no. 16, p. 4.

13 1905-1917-1925, Kino Zhurnal A.R.C. 1925, no. 11-12, p. 1. 
sary to make films about the revolution; in addition, to dedicate these pictures to anniversaries of 1905 and 1917. For example, so appeared feature films such as Horrors of the Past (1925), which tells how Georgian people took part in the Revolution in 1905. The film Against the Will of the Fathers (1926) with the same plot presents the story of the contribution of the Jewish people in the Russian revolution of 1905 .

In 1929 the cinema press wrote that the main objective is to attract the national film of the Republics to the construction of socialism ${ }^{14}$. It pointed out that the national cinema had not yet focused on the mass audience, and as a rule, local film studious had not fulfilled official tasks, but rather they decided what was appropriate to shoot and what was not on their own.

In 1924 the magazine "Kino i Zyttia" (Cinema and Life) gave an example of the VUFKU ${ }^{15}$ as the largest USSR cinema producer whose target audience for some reason included "petty bourgeoisie" analyzing captured films ${ }^{16}$. This article hinted that cinema staff on the local level in the Republics did not take into account the instructions of the central authorities. On the pages of cinema newspapers from time to time there appeared articles that criticized the republican cinema studios for another point of view on cinema production. In 1929 the VUFKU was again accused of using "vulgar" topics and releasing such films as For the Monastery Walls (1928), Clown George (1928), and The Great Grief of a Little Woman (1929) ${ }^{17}$. Instead, it stressed the necessity of creating films such as the picture of the January uprising of workers in Kiev in 1918, called Arsenal made by the VUFKU in 1928. Or, as another example, the film Eliso realized by Hoskinprom Georgia in 1928, which was based on the events of 1864 when tsar's power made an attempt to evict the Highlanders from the Caucasus ${ }^{18}$.

Typically, each cinema newspaper or magazine had a special column which was called "kino nacmeniv". In English it means "films of national minorities". That column presented a brief overview of those films: plot synopsis, the names of the actors who starred in the main roles, etc. Some films were analyzed and criticized for what was inappropriate in the plots according to the central instructions and plans ${ }^{19}$. However, this criticism was considered normal in the cinema industry. Let us criticize is the title of the article with a direct example of the discussion around

\footnotetext{
14 Natsionalnoe kino, Kino i Zhyzn 1929, no. 3, p. 2.

15 All-Ukrainian Photo-Cinema-Directorate.

${ }_{16}$ Natsionalnoe kino, Kino i Zhyzn 1924, no. 17, p. 5.

${ }^{17}$ Ibidem, 1929, no. 3, p. 1.

${ }^{18}$ Ibidem.

19 Ibidem.
} 
films $s^{20}$. As usually, the central press criticized and accused republic film studios and the local press answered or ignored them. For example, Ukrainian republican newspaper "Kino Tyzden" in 1927 wrote that the industry addresses cultural and educational problems, however, they continued making films that they wanted to make $^{21}$. First of all, critics from the central press analyzed an ideological packed story. Films talk about the revolution, or find fault with the imperial times, or show the new Soviet life, or are helpful in building a new society. For example, the Georgian film Three Lives was criticized for the fact that "it has no social value and therefore is devoid of cinematic possibilities" 22 .

If the cinema press criticized films of national minorities they always used the VUFKU as an example. That criticism was also associated with the Jewish films that were produced by the VUFKU. The cinema journal "Kino Zhurnal" stated that the majority of the Jewish people live on the Ukrainian territory and it is natural that the VUFKU produced films about the Jewish life ${ }^{23}$. Moreover, the Jewish theme should be presented with the right approach, focusing on the revolutionary events that took place in the middle of the community and not on the traditional way of life $\mathrm{fe}^{24}$.

In 1925 "Kino Zhurnal" wrote that a director and an ethnographer must work on a script together. The ethnographer knows a lot about the life of the nation minority, not only from books but also from own life experience, and he always should know their language in order to correctly convey their traditional life ${ }^{25}$. Solomon Mikhoels was considered as one of the best actors and directors, who knew ethnographic subtleties of people's lives, though not marked who were that "people". Obviously, it was the Jews, because the 1925 Solomon Mikhoels starred in the main role in the film Jewish Luck. The feature film Jewish Luck was called "the first successful comedy" due to the comic and ironic image of MenachemMendel, played by Solomon Mikhoels. But other images from the same film were mentioned as incomplete fuzzy characters, such as Bailey and Zalman ${ }^{26}$. Researcher A. Breytman classifies Jewish films into three models of the Jewish cinema ${ }^{27}$. According to his research, the film Jewish Luck belongs to the third

\footnotetext{
${ }_{20}$ M. Kapchynsky, Haj nas krytykujyt, Kino Thyzden 1927, no. 4, p. 1.

${ }^{21}$ Ibidem.

22 Novosti ekrana, Kino. Leninhradskoe prilozenie 1925, no. 17, p. 1.

${ }^{23}$ Yan-ya. Glaza kotorye vide li, Kino i Zhyzn 1929, no. 2, p. 4.

${ }^{24}$ Ibidem.

${ }^{25}$ H. Hersonsky, Objektyvom k zyzny narodom, Kino Zhurnal. A.R.C. 1925, no. 6-7, p. 28.

${ }^{26}$ Ibidem.

${ }^{27}$ S. Breytman, "Yevreyskoe schastie" rosiyskoho kino, http://icarp.ru/konferens/konf_2011/ konf_idish_2011/Breitman.pdf, (accessed 24.05.2015).
} 
model, which is called the national-romantic. In his point of view, the film was intended as a propaganda product, which showed the miserable state of the Jewish poor in the towns, because of the tsar's policy; instead of that, the film is about the traditional life in the shtetl (town) ${ }^{28}$. To national romantic films include the picture Benya Krik (1926), because it shows the tradition life of "small-town" on the Moldavanka ${ }^{29}$ Street in Odessa ${ }^{30}$.

The first type of cinema Judaica is the active model associated with the class struggle and includes the contribution of Jews in the construction of the "bright future". The film Against the Will of the Fathers (1926) should be in the framework of the first model, which refers to the Jewish woman who had gone to study and became involved in revolutionary activities.

The second model is passive, in which tsar's power humiliated the Jewish people. These include the film His Excellency, whose second name Hirsch Lekkert (1927) about the humiliation of Jews who participated in the May Day demonstration of workers. The researcher says that the first and second models were present in the "Soviet-Jewish" film occasionally changing each other according to subjects ${ }^{31}$.

In such a way, among the instruments to influence the national communities and national minorities was cinema. However, in the early 1920s Bolsheviks faced the problem of technical and human resources in the film industry that led to using imported products. The national policy of the Bolshevik was spread among national minorities in their own language and involved them in building a socialist society. "National" films according to the cinema press and feature films from 1925-1929 would depict tsarist Russia only in the negative way and show the Revolution as a symbol of revival and liberation. Typical scenes of feature films were formed during this period, usually based on 1905 and 1917, while films about mid-nineteenth century depicted the powerless life of national minorities in the tsarist Russia. For example, films with Jewish themes fit into this general scheme, the only thing that distinguishes them is the theme of pogroms and small-town life in the line of Settlement.

\footnotetext{
${ }^{28}$ Yiddish: לטעט, a small town with large Jewish population.

${ }^{29}$ Moldavanka is a historical part of Odessa province of southern Ukraine.

${ }^{30}$ S. Breytman, op. cit.

${ }^{31}$ Ibidem.
} 


\section{The Case of Jewish Feature Cinema}

As I have already mentioned, during the 1920s Soviet film studios released a limited number of productions, while showing foreign movies. In 1922-1923 they made 12 feature films, from 1924 to 1925 the figure increased to 77, and already by 1929 the entire Soviet film industry was able to produce 120 movies $^{32}$. The main Republics where movies focused on the Jewish themes were Ukraine and Belarus. These movies came out in the Soviet Union, as evidenced by the cinema press. Of the 12 films preserved, only 5 are in the Soviet version. These are Benya Krik $^{33}$, Jewish Luck ${ }^{34}$ (Evreiskoe Schastye in the original version), Hirsh Lekert ${ }^{35}$, Against the Will of the Fathers ${ }^{36}$ (Protiv Voli Ottsov in the Russian version), Five Brides $^{37}$ (Pjat' nevest in the original version).

Film images of Jews in the Soviet cinema can be logically divided into traditional and "new". The traditional image of the Jew was presented as the traditional way of life in the Jewish community. Typically, there were images of the Rabbi and Jews from the shtetl, who also tried to maintain their traditions and practices. The image of the Rabbi in the Soviet cinema is that of a conservative man who prefers to keep everything as it was. The film His Excellency (1927) and the picture Five Brides (1929) show the Rabbi as a man who stayed an authority for a part of the community, as well as for officials cooperating with him. Rabbis in the cinema imagery became symbols of the past.

The traditional scheme presented the shtetl as a poor and cheated place. Often its inhabitants are cheated by wealthy Jews or policemen, who are symbols of tsar's orders. In these films ordinary Jews always suffer from the imperial power but in the Soviet time they are given great opportunities in the big city. Following the logic of the script for the film Wandering Stars, the Jew would not be able to realize his talents without leaving a shtetl. In the small town a Jew must obey the rules of the town and observe traditions; on the other hand, in the big city a Jew can be free. Films showed the shtetl in the Soviet interpretation without the demonstration of Jewish traditions; that is why this issue became prohibited at the end of the 1920s. Increasingly, critics insisted that the main issues in the cinema are social movements taking place in the town and not its traditions.

\footnotetext{
${ }^{32}$ St. Plaggenborg, Revolution and Culture. Cultural Guidelines in the Period between the October Revolution and the Stalinist age, Saint Petersburg 2000, p. 216.

33 Benya Krik, dir. V. Vilner, VUFKU (Odessa) 1926, 105 min.

${ }_{34}$ Jewish Luck, dir. A. Granovsky, Hoskyno 1925, 100 min.

35 Hirsh Lekert, G. Roshal, Belhoskyno 1927, 66 min.

${ }^{36}$ Against the will of the fathers, E. Ivanov-Barkov, Proletkino 1927, $44 \mathrm{~min}$.

37 Five brides, dir. A. Solovyov, VUFKU (Odessa) 1929, 57:12 min.
} 
New images of Jews in the Soviet cinema can be ascribed to the general context of revolutionist images that were created during the 1920s. Films are full of evidences why Jews had to participate in the revolution. First, Jews were portrayed in the movies as powerless and defenseless, and secondly, they were present on the screen as victims of pogroms. "New" Jews became revolutionaries and "new" Jewish women received features of the Soviet woman. Heroes-Revolutionaries showed how the Jewish people struggled with the tsar's power and their activism in the revolutionary events. These films create the image of the hero, who is trying to take initiative in organizing the struggle against the old order and the social inequality. However, it concerned not all of their community, frequently they present Jews who supported the tsar power; it is generally orthodox Jews, Zionists, and Rabbis.

How the traditional image was transformed into a "new" in 1920s was brightly demonstrated by Benya Krik. Its main protagonist is a fictional character in a collection of short stories The Odessa Tales written by Isaac Babel. Benya Krik is well-known as The King; he was the leader of a group of thugs and smugglers. They were operating together in the Jewish ghetto Moldavanka in Odessa. Indeed, Isaak Babel used the image of the Yaponchik cult as a strong personality in Odessa as a model for Benya Krik in his The Odessa Tales. But according to the Soviet interpretation, Krik became an entirely different character.

In the cinema press the image of Krik provoked a discussion. The main question was how Krik should be portrayed: as a traditional Jew from Moldavanka, as it was in Isaac Babil's version, or as a thief and a gangster in a negative light. Eventually, the film's director Vladimir Vilner explained his point of view and the position of the VUFKU that Babel's script touched the issue of the Civil War, which is why the ideological line needs more attention. The author noted that they are not interested in the everyday life and supposed that original Benya Krik would help to remember who Mishka Yaponchik was, and it could be a danger for the authorities ${ }^{38}$. Obviously, Vladimir Vilner meant that the hero of Odessa was symbolic and remembering recent events that the Soviet authorities would like to avoid. The cinema press wrote that Odessa has two "national" heroes: Mishka Yaponchik and Isaac Babel ${ }^{39}$. Who are these "national" heroes and what does it mean that "nationality" is not mentioned in the articles about Benya Krik. Nobody directly wrote that this film is about a Jewish character. However, they wrote about Odessa in the pre-revolutionary years that it had a specific atmosphere, an

${ }_{38}$ T. Derevjanko, J. Morozov, Jevrejskie kinematografisty v Ukraine v 1910-1945, Kyiv 2004, p. 154.

${ }^{39}$ D. Mallory, Krik "Beni Krika”, Sovetskiy ekran 1927, no. 7, p. 7. 
ethnography and everyday life which was filled with gangster's rules of the Deribasovskaya street and poverty of the Moldavanka ${ }^{40}$.

Director V. Vilner in the article called Vtoroe rozhdenie Benni Kirka (Rebirth of Benya Krik) used the phrase "small-town Moldavanka" and remarked that it is poor. This is a completely new Soviet concept because everything reminding of a small-town is unacceptable and it would be better to avoid it or show it as poor and closed. According to V. Vilner, a small-town is always depicted in a negative sense. But in the film there are two interesting scenes: a grotesque Jewish wedding and a funeral at the Jewish cemetery. Actually, it is a sign of provincialism to respect the traditions and religion. As for the hero, Benya Krik was not ironic and funny, instead he appeared cruel and arrogant. This can be viewed as an emphasis shift from the traditional to the new image. Benya Krik in the Soviet interpretation does not pursue traditions, he is not interested in the revolutionary affairs that he just read about in the newly created (in 1917) newspaper "Izvestia" and that is all. A careful analysis of the film reveals that Benya Krik was actually in a limited number of scenes, he is lost among many other characters on the screen. With the aim of getting rid of romantic hero the director made him inconspicuous.

The Bolsheviks faced problems in the cinema industry associated with the lack of resources. The purpose of the Bolshevik's policy was to get the cinema industry under control. The cinema was considered a propaganda tool, so the Bolsheviks used it to maintain new ideology. Thus, in mid-1920s crystallized the schema of "national" cinema heroes who had new appearance and an ideological context. Constructed scheme of film plots and image of heroes were suited to all national minorities of the Soviet Union. It became a universal scheme for the Soviet cinema. Finally, at the beginning of the 1930s "national" features were almost erased.

${ }^{40}$ V. Vilner, Vtoroe rozhdenie Beni Kryk, Sovetskiy ekran 1927, no. 2, p. 4. 